\title{
Pathogenicity of Evlachovaea sp (Hyphomycetes), a new species isolated from Triatoma sordida, in Chagas' disease vectors
}

\author{
Patogenicidade de Evlachovaea sp (Hyphomycetes), uma nova espécie \\ isolada de Triatoma sordida, para vetores da doença de Chagas
}

\author{
Christian Luz ${ }^{1}$, Luiz Fernando Nunes Rocha ${ }^{1}$ and Ionizete Garcia Silva ${ }^{1}$
}

\begin{abstract}
Evlachovaea sp was tested on nymphs of 5 Triatoma spp 5 Rhodnius spp, Panstrongylus herreri and Dipetalogaster maximus at $25^{\circ} \mathrm{C}, 75 \%$ humidity and humidity $>98 \%$. Most species showed susceptibility to fungal infection at high humidity. Mortality was reduced at $75 \%$ humidity. Fungal development was observed on $69.5 \%$ of cadavers.
\end{abstract}

Key-words: Evlachovaea. Triatominae. Pathogenicity. Vector control.

\section{RESUM0}

Evlachovaea sp foi testada em ninfas de 5 Triatoma spp, 5 Rhodnius spp, Panstrongylus herreri e Dipetalogaster maximus a $25^{\circ} \mathrm{C}, 75 \%$ umidade e umidade $>98 \%$. A maioria das espécies foi suscetível à infecção em umidade alta. Mortalidade foi reduzida a $75 \%$ de umidade. 0 fungo desenvolveu em $69.5 \%$ dos cadáveres.

Palavras-chaves: Evlachovaea. Triatominae. Patogenicidade. Controle de vetores.

Entomopathogenic fungi such as Beauveria bassiana and Metarhizium anisopliae were shown to be active against triatomine bugs under laboratory conditions ${ }^{2}{ }^{4}$. However, only a few field tests have been reported, and there is almost no published information about pathogenic fungi isolated from field-collected triatomine cadavers. Parameswaran and Sankaran (1979) reported B. bassiana on the triatomine bug Linshcosteus sp in India. Recently another fungus identified as a new species of Evlachovaea, a genus described in Russia ${ }^{1}$, was found on a dead Triatoma sordida nymph in central Brazil, and its pathogenicity was documented against Triatoma infestans $s^{3}$. Herein we report results on the pathogenicity of the Evlachovaea sp in other triatomine species.

All triatomines tested, 5 Triatoma spp, 5 Rhodnius spp, Panstrongylus herreri, and Dipetalogaster maximus, originated from the Institute of Tropical Pathology and Public Health, Goiânia, Brazil. Insects were reared at $25 \pm 0.5^{\circ} \mathrm{C}, 75$ $\pm 5 \%$ relative humidity $(\mathrm{RH})$, and a photoperiod of $12: 12$ ( $\mathrm{L}: \mathrm{D})$ $h$. They were blood-fed on chickens at 2-week intervals. The fungus was cultivated on complete medium and incubated for
15 days at $25 \pm 0.5^{\circ} \mathrm{C}, 75 \pm 5 \% \mathrm{RH}$, and a photoperiod of $12: 12$ ( $\mathrm{L}: \mathrm{D}) \mathrm{h}^{3}$. For the tests, conidia were suspended in $10 \mathrm{ml}$ of sterile $0.1 \%$ Tween 80 and adjusted to $3.3 \times 10^{6}, 10^{7}, 3.3 \times 10^{7}$, $10^{8}, 3.3 \times 10^{8}$ and $10^{9}$ conidia/ml, corresponding to between $2.4 \times 10^{3}$ and $8.0 \times 10^{5} \mathrm{CFU}$ (colony-forming unit) $/ \mathrm{cm}^{2}$ treated surface $e^{4}$. Ten recently molted and unfed third instar nymphs (N3) of the various species were directly sprayed with $5 \mathrm{ml}$ of each concentration using a Potter spray tower (Burkard Ltd., Hertfordshire, UK) . Control insects were treated with $0.1 \%$ Tween 80 only. N3 were placed on filter paper in plastic Petri dishes $(90 \times 15 \mathrm{~mm})$ and then incubated in a test chamber ( $33 \times 37 \times 22 \mathrm{~cm}$ ) at $\mathrm{RH} 75 \%$, humidity close to saturation ( $\mathrm{RH}>98 \%$ ) , $25 \pm 0.5^{\circ} \mathrm{C}$ and a photoperiod of $12: 12$ (L:D) h. Humidity of 75\% inside the test chamber was regulated with a saturated solution of $\mathrm{NaCl}$. Insects were not fed during the assays. Mortality of nymphs was monitored daily. Lethal concentrations to kill $50 \%$ and $90 \%\left(\mathrm{LC}_{50}\right.$ and $\mathrm{LC}_{90}$ ) were calculated by probit analysis. Cadavers were placed in Petri dishes and incubated at $\mathrm{RH}>98 \%$ and $25^{\circ} \mathrm{C}$ during 20 days.

1. Institute of Tropical Pathology and Public Health, Federal University of Goiás, Goiânia, GO, Brazil

This work was supported by CNPq Centro-Oeste (Conselho Nacional de Desenvolvimento Científico e Tecnológico).

Address to: Dr. Christian Luz. Universidade Federal de Goiás, Caixa Postal 131, 74001-970 Goiânia, G0.

Tel: 5562 209-6113, Fax: 5562 521-1839.

e-mail: wolf@iptsp.ufg.br

Recebido para publicação em 30/6/2003

Aceito em 3/2/2004 
Fungal emergence of Evlachovaea sp on cadavers and external conidiogenesis were examined daily.

Most triatomine species tested were found susceptible to the Evlachovaea sp isolate at $\mathrm{RH}>98 \%$. Susceptibility of insects was clearly influenced by humidity. At RH 75\% mortality was distinctly reduced for all species. Results showed a general relationship between dosage and fungal activity against insects. This was also observed for T. infestans ${ }^{3}$. First insects of most triatomine species succumbed to the fungus 5-7 days after application of $\geq 3.3 \times 10^{7}$ conidia/ml independently of humidity tested. Mortality of T. vitticeps and T. delpontei initiated after 8 and 9 days incubation at $\mathrm{RH}>98 \%$, respectively, and the first dead N3 of T. picturata exposed to RH 75\% were found 12 days after treatment. Total mortality was observed at the highest doses ( $3.3 \times 10^{8}$ and $10^{9}$ conidia/ml) and humidity close to saturation, except for T. vitticeps, T. picturata and T. sordida which had mortality rates of $10 \%, 60 \%$ and $80 \%$, respectively, 20 days after exposure at $\mathrm{RH}>98 \%$. Values of $\mathrm{LC}_{50}$, and $\mathrm{LC}_{90}$ are presented in Table 1. $\mathrm{LC}_{50}, 15$ days after incubation at $\mathrm{RH}>98 \%$, varied from $3.18 \times 10^{3} \mathrm{CFU} / \mathrm{cm}^{2}$ ( $\mathrm{R}$. neglectus) to $4.34 \times 10^{5} \mathrm{CFU} /$ $\mathrm{cm}^{2}$ ( T. sordida). At RH $75 \%$ only P. herreri $\left(1.37 \times 10^{5} \mathrm{CFU}\right.$ $\left.\mathrm{cm}^{2}\right)$ and R. ecuadoriensis $\left(3.11 \times 10^{5} \mathrm{CFU} / \mathrm{cm}^{2}\right)$ presented sufficient mortality to calculate the $\mathrm{LC}_{50}$. After 20 days incubation at humidity close to saturation mortality of $\mathrm{T}$. delpontei, R. neglectus, R. nasutus and D. maximus were too high to calculate $\mathrm{LC}_{50}$ and varied between $2.93 \times 10^{3} \mathrm{CFU} / \mathrm{cm}^{2}$ (R. prolixus) and $1.44 \times 10^{5} \mathrm{CFU} / \mathrm{cm}^{2}$ (T. picturata) for the other species. At $\mathrm{RH} 75 \% \mathrm{LC}_{50} 20$ days after incubation was $1.12 \times 10^{5} \mathrm{CFU} / \mathrm{cm}^{2}, 1.68 \times 10^{5} \mathrm{CFU} / \mathrm{cm}^{2}$ and $3.71 \times 10^{5} \mathrm{CFU} / \mathrm{cm}^{2}$ for P. herreri, R. ecuadoriensis and D. maximus, respectively (Table 1). Control mortality at both humidities was $\leq 10 \%$ during the assay, irrespective of the species.

Among all cadavers regardless of triatomine species, humidity or dose tested, $50.8 \%$ of the cadavers showed outgrowth of Evlachovaea sp only, $18.7 \%$ were found with mixed development of Evlachovaea sp and other saprophytic fungi,

Table 1 - Lethal concentrations $\left(\mathrm{LC}_{50}\right.$ and $\left.\mathrm{LC}_{90}\right)\left(\mathrm{CFU} / \mathrm{cm}^{2}\right)$ and respective confidence intervals (95\% C.I.) of Evlachovaea sp. calculated for triatomine third instar nymphs, 15 and 20 days after exposure at $75 \%$ and $>98 \%$ relative humidity and $25^{\circ} \mathrm{C}^{1}$.

\begin{tabular}{|c|c|c|c|c|c|}
\hline \multirow{4}{*}{$\frac{\text { Species }}{\text { Triatoma delpontei }}$} & \multirow{4}{*}{$\frac{\text { Humidity (\%) }}{75}$} & \multicolumn{4}{|c|}{ Time after inoculation ( days) } \\
\hline & & \multicolumn{2}{|c|}{15} & \multicolumn{2}{|c|}{20} \\
\hline & & \multicolumn{2}{|c|}{$\begin{array}{l}\mathrm{LC}_{50} \\
\left(\mathrm{CFU} \times 10^{5} / \mathrm{cm}^{2}\right)(95 \% \text { C.I. })\end{array}$} & \multicolumn{2}{|c|}{$\begin{array}{lr}\mathrm{LC}_{50} & \mathrm{LC}_{90} \\
(\mathrm{CFU} x & \left.10^{5} / \mathrm{cm}^{2}\right)(95 \% \text { C.I. })\end{array}$} \\
\hline & & $*$ & $*$ & $*$ & $*$ \\
\hline & $>98$ & $0.20^{\mathrm{a}, \mathrm{b}}(0.05-0.55)$ & $5.02^{\mathrm{b}, \mathrm{c}}(1.36-402.0)$ & ** & $* *$ \\
\hline \multirow[t]{2}{*}{ Triatoma lecticularia } & 75 & * & $*$ & * & $*$ \\
\hline & $>98$ & $0.89^{b, c}(0.32-2.28)$ & $1.54^{\mathrm{b}, \mathrm{c}}\left(1.07-2.61 \times 10^{4}\right)$ & $0.20^{c, d}(0.12-1.06)$ & $0.52^{\mathrm{a}, \mathrm{b}}(0.27-279.0)$ \\
\hline \multirow[t]{2}{*}{ Triatoma picturata } & 75 & $*$ & $*$ & $*$ & $*$ \\
\hline & $>98$ & $1.66^{c}(0.84-8.30)$ & $9.90^{b, c}(3.27-796.0)$ & $1.44 \mathrm{~d}(0.74-5.73)$ & $8.44^{\mathrm{a}, \mathrm{b}}(2.93-290.0)$ \\
\hline \multirow[t]{2}{*}{ Triatoma sordida } & 75 & $*$ & $*$ & $*$ & $*$ \\
\hline & $>98$ & $4.34^{c}(1.74-30)$ & $67.40^{c}\left(13.80-6.91 \times 10^{3}\right)$ & $1.08 \mathrm{~d}(0.60-2.69)$ & $6.97^{a, b}(2.79-51.20)$ \\
\hline \multirow[t]{2}{*}{ Triatoma vitticeps } & 75 & * & $*$ & * & * \\
\hline & $>98$ & $*$ & $*$ & $*$ & $*$ \\
\hline \multirow[t]{2}{*}{ Panstrongylus herreri } & 75 & $1.37^{c}(0.69-5.26)$ & $8.77^{\mathrm{b}, \mathrm{c}}(2.95-235.0)$ & $1.12^{\mathrm{d}}(0.51-5.36)$ & $12.3^{\mathrm{a}, \mathrm{b}}(3.21-682.0)$ \\
\hline & $>98$ & $0.06^{\mathrm{a}}(0.02-0.13)$ & $0.63^{\mathrm{a}, \mathrm{b}}(0.28-3.89)$ & $0.05^{\mathrm{a}, \mathrm{b}}(0.02-0.09)$ & $0.27^{a}(0.13-1.64)$ \\
\hline \multirow[t]{2}{*}{ Rhodnius ecuadoriensis } & 75 & $3.11^{c}(1.29-27.6)$ & $59,30^{c}\left(11,0-3.4 \times 10^{4}\right)$ & $1.68^{d}(0.70-6.66)$ & $33.50^{\mathrm{a}, \mathrm{b}}(7.85-429.0)$ \\
\hline & $>98$ & $0.33^{\mathrm{a}, \mathrm{a}}(0.18-0.55)$ & $0.93^{b}(0.56-4.62)$ & $0.13^{\mathrm{b}, \mathrm{c}}(0.07-0.21)$ & $0.37^{a}(0.22-1.38)$ \\
\hline \multirow[t]{2}{*}{ Rhodnius nasutus } & 75 & $*$ & $*$ & $*$ & $*$ \\
\hline & $>98$ & $0.04^{\mathrm{a}}(0.02-0.12)$ & $0.64^{\mathrm{a}, \mathrm{b}}(0.22-4.45)$ & ** & $* *$ \\
\hline \multirow[t]{2}{*}{ Rhodnius neglectus } & 75 & $*$ & $*$ & $*$ & $*$ \\
\hline & $>98$ & $0.03^{\mathrm{a}}(0.01-0.06)$ & $0.11 \mathrm{a}(0.06-0.55)$ & $* *$ & ** \\
\hline \multirow[t]{2}{*}{ RRhodnius prolixus } & 75 & $*$ & $*$ & $*$ & $*$ \\
\hline & $>98$ & $0.06^{\mathrm{a}}(0.01-0.19)$ & 0.57 a,b (0.19-6.34) & $0.03^{\mathrm{a}}(0.01-0.05)$ & $0.08^{\mathrm{a}}(0.05-11.1)$ \\
\hline \multirow[t]{2}{*}{ RRhodnius robustus } & 75 & $*$ & $*$ & $*$ & $*$ \\
\hline & $>98$ & $0.35^{b}(0.22-0.58)$ & $0.78^{a, b}(0.5-2.76)$ & $0.22^{\mathrm{b}, \mathrm{c}}(0.13-0.44)$ & $0.38^{\mathrm{a}}(0.26-15.1)$ \\
\hline \multirow[t]{2}{*}{ Dipetalogaster maximus } & 75 & $*$ & $*$ & $3.71^{\mathrm{d}}\left(1.02-6.59 \times 10^{2}\right)$ & $1.68 \times 10^{2 b}\left(17.0-10^{16}\right)$ \\
\hline & $>98$ & $0.09^{\mathrm{a}}(0.03-0.19)$ & $0.94 \mathrm{a}, \mathrm{b}(0.43-4.10)$ & $* *$ & $* *$ \\
\hline
\end{tabular}

${ }^{1}$ five ml suspended conidia at six doses between $3.3 \times 10^{6}$ and $10^{9} \mathrm{conidia} / \mathrm{ml}$, corresponding to between $2.4 \times 10^{3}$ and $8.0 \times 10^{5} \mathrm{CFU}$ ( colony forming unit) $/ \mathrm{cm}^{2}$ treated surface, were applied on 10 recently molted and unfed individuals each using a Potter spray tower. $(*)$ cumulative mortality insufficient, $(* *)$ too high to calculate $\mathrm{LC}_{50190}$. Values followed by differentletters $(\mathrm{a}, \mathrm{b}, \mathrm{c}, \mathrm{d})$ are significantly different $(\mathrm{P}<0.05)$. 
$25 \%$ with unidentified saprophytic fungi, and $5.5 \%$ showed no external fungi. Results underline the need to study entomopathogenic fungi for control of triatomine bugs.

\section{ACKNOWLEDGEMENTS}

Authors thank Carmeci NElias for technical support, and Richard A Humber for the critical review of the manuscript.

\section{REFERENCES}

1. Borisov BA, Tarasov KL. Notes on biodiversity of causal agents of invertebrate mycoses in Adjaria ( southwestern Georgia). I. Evlachovaea kintrischica gen et sp. nov., 1999. (Hyphomycetes) from Kintrishi reservation. Micologiya i Fitopatologiya 33: 248-256.

2. Lecuona RE, Edelstein JD, Berretta MF, Rossa FR, Argas JA. Evaluation of Beauveria bassiana (Hyphomycetes) strains as potential agents for control of Triatoma infestans (Hemiptera: Reduviidae). Journal of Medical Entomology 38: 172-179, 2001.

3. Luz C, Rocha LFN, Humber RA. Record of Evlachovaea sp on Triatoma sordida in the State of Goiás, Brazil, and its activity against Triatoma infestans. Journal of Medical Entomology 40:451-454, 2003.

4. Luz C, Tigano MS, Silva IG, Cordeiro CMT, Aljanabi SM. Selection of Beauveria bassiana and Metarhizium anisopliae to control Triatoma infestans. Memórias do Instituto Oswaldo Cruz 93: 839846, 1998.

5. Parameswaran G, Sankaran T. Record of Beauveria bassiana (Bals.) Vuill. on Linshcosteus sp. (Hemiptera: Reduviidae: Triatominae) in India. Journal of Entomological Research 1: 113-114, 1979. 